Kiséry, András. "Lénárt-Cheng, Helga, and Zsuzsa Vajdovics. 2015. Lénárd Sándor: Világok Vándora ['Alexander Lenard: Wanderer of Worlds']. Budapest: L'Harmattan. 180 pp. Illus." Hungarian Cultural Studies. e-Journal of the American Hungarian Educators Association, Volume 10 (2017): http://ahea.pitt.edu DOI: 10.5195/ahea.2017.282

\title{
Lénárt-Cheng, Helga, and Zsuzsa Vajdovics. 2015. Lénárd Sándor: Világok Vándora ['Alexander Lenard: Wanderer of Worlds']. Budapest: L'Harmattan. 180 pp. Illus.
}

\author{
Reviewed by András Kiséry," The City College of New York (CUNY)
}

Lénárd Sándor: Világok Vándora is the first book written on Sándor Lénárd, or Alexander Lenard (1910-1972), a fascinating polymath and polyglot best known for his translation of A.A. Milne's Winnie-the-Pooh into Latin, but the three volumes of life-writing he published in the last decade of his career clearly deserve critical attention, as well. The two authors have both written about Lenard before. Zsuzsa Vajdovics has not only translated some of Lenard's works from Hungarian into Italian and from Italian into Hungarian, she has also been active in helping to bring Lenard's papers to Hungarian archives and in organizing a Lenard Seminar, and later a Lenard Society, in Budapest. Her co-authored book with Helga Lénárt-Cheng draws on their previously published work (e.g., in this journal's vol. 7, 2014, Lénárt-Cheng's article: https://ahea.pitt.edu/ojs/index.php/ahea/article/view/3), but this is a more inclusive monograph that aims to encompass Lenard's entire oeuvre and provide a starting point for further scholarship on his work. After a biographical overview (13-45), the two authors survey Lenard's writings by genre (46-121), discuss his other activities (122-137), and conclude with an appendix of illustrations, a bibliography, and a list of Lenard's correspondents.

Presented as a linear narrative - as it actually is in this book's first chapter - the biography reads like a picaresque novel, the story of a remarkably talented man whose life was shaped by accident, luck, and of course his own stunning ability and willingness to move among languages, cultures, and fields of learning. Lenard's own approach to life writing, however, was different: he used personal experience as a vehicle and occasion for historical and cultural commentary. Of his three book-length autobiographical essays, only the earliest, his memoirs of his Italian years (Am Ende der Via Condotti, 1963 / Római történetek, 1969) more or less follows the chronology of the events described. The second, (Kuh auf dem Bast, 1963 / The Valley of the Latin Bear, 1965 / Völgy a világ végén, 1967), is a sociographical report about the lives of the German and Italian settlers in Santa Caterina, Brazil, and his own life among them. His last book (Egy nap a láthatatlan házban, 1969 / Ein Tag im unsichtbaren Haus, 1970) weaves together personal memories and historical anecdotes with essayistic reflections, organizing them into an account of a typical day in a withdrawn life confined to a small house and the surrounding garden.

*akisery@ccny.cuny.edu

$($ (c) $)$ EY

ULIS D-Serk
New articles in this journal are licensed under a Creative Commons Attribution 4.0 International License.

This journal is published by the University Library System of the University of Pittsburgh as part of its D-Scribe Digital Publishing Program and is cosponsored by the University of Pittsburgh Press 
Kiséry, András. "Lénárt-Cheng, Helga, and Zsuzsa Vajdovics. 2015. Lénárd Sándor: Világok Vándora ['Alexander Lenard: Wanderer of Worlds']. Budapest: L'Harmattan. 180 pp. Illus.” Hungarian Cultural Studies. e-Journal of the American Hungarian Educators Association, Volume 10 (2017): http://ahea.pitt.edu DOI: 10.5195/ahea.2017.282

After the biographical chapter, which draws on published and manuscript sources to offer the most detailed account of the facts of Lenard's life hitherto available, the two authors follow Lenard's example in so far as they are attending to discrete genres, formal features, and aspects of the entirety of Lenard's output and outlook, rather than writing a chronologically organized intellectual and literary biography. This focus on such topics as Lenard's authorial strategies, his ideas about translation, the classicism of his poetry, his theory of dreams, the problem of truth and fiction in his autobiographies, etc., tends to eclipse the shape and intellectual content of the individual works, and also makes it hard for the reader to discern the shifts in Lenard's thought and writing over his career.

This is not to say that the authors do not attend to historical context. Throughout the book, they discuss Lenard's personal experiences based on his published memoirs, unpublished writings, and correspondence. Lénárt-Cheng and Vajdovics show how important his correspondence was to Lenard's personal and intellectual life (56-66), and argue that the republic of letters was the model for the community in which he sought to imagine himself (49-52). But they also suggest that the surviving correspondence does not allow us to reconstruct Lenard's literary trajectory (56). Lenard himself also appears to have had little to say about what impressed him in contemporary literature, and since Lénárt-Cheng and Vajdovics have no interest in trying to trace the unacknowledged influences and resonances of other authors in Lenard's work, the portrait they draw does ultimately rather little to place Lenard on the literarycultural map of the twentieth century. Their work, while suggestive, does not reveal much about how Lenard's encounters with contemporary literary life may have been shaping his formal and thematic choices, his understanding of migration, of linguistic and cultural change and loss, and how the intellectual vocabulary he acquired from some members of his generation and the one that preceded it helped him articulate his exilic experience.

Lénárt-Cheng and Vajdovics explore Lenard's Hungarian affiliations. Even though Lenard's first literary language was German (he grew up in Austria, wrote poetry in German, and translated poetry into German throughout his life), they find much less evidence of his German literary connections and interests (22-23). From their account it appears that after the Anschluss forced him to leave Austria, and especially after he left Italy in 1952 (a letter from Thomas Mann to Lenard dates from 1945, see 143), Lenard continued to work and correspond in German and several other languages, but the one contemporary literary culture of which he had an active awareness was the Hungarian (36). Nevertheless, when the authors do bring to bear Hungarian analogies and parallels on formal and thematic analysis, this mostly shows Lenard's distance from his contemporaries. For example, the two authors point out that Lenard had almost nothing in common with such Hungarian émigré writers of his generation as Lajos Zilahy, Albert Wass, or József Nyírö, aside from a general tendency towards the anecdotal (48). This is an odd yet unsurprising assertion: odd because Zilahy and Nyírö were two decades older than Lenard, and unsurprising because Nyírö was an active supporter of fascism in the 1940s and Wass became a key figure of an ethno-nationalist and antisemitic strand in Hungarian literary culture; whereas Lenard came from an assimilated German-Jewish background, his relationship to Hungary was marked by the fact that his brother was murdered in a forced labor camp in 1944 (87), and his Italian memoirs contain vitriolic accounts of the farcical stupidity of Mussolini's regime (see Lénárt-Cheng's review of the English translation of the book in this journal's vol. 8, 2015: https://ahea.pitt.edu/ojs/index.php/ahea/article/view/197). 
Kiséry, András. "Lénárt-Cheng, Helga, and Zsuzsa Vajdovics. 2015. Lénárd Sándor: Világok Vándora ['Alexander Lenard: Wanderer of Worlds']. Budapest: L'Harmattan. 180 pp. Illus.” Hungarian Cultural Studies. e-Journal of the American Hungarian Educators Association, Volume 10 (2017): http://ahea.pitt.edu DOI: 10.5195/ahea.2017.282

Lénárt-Cheng and Vajdovics compare Lenard's distance from Hungarian émigré communities to the isolation of Carl Kerényi, Sándor Márai, and Pál Rónai (49), without pursuing these parallels or registering the paradoxical fact that of the three examples of isolated existence, Lenard was a personal acquaintance of both Kerényi and Rónai. Tracing these and similar connections might in fact help identify the sources and perhaps the originality of Lenard's thought. For example, Lénárt-Cheng and Vajdovics devote a chapter to Lenard's work as a translator, and from his scattered remarks they manage to reconstruct his pragmatic yet ultimately skeptical sense of the limits of translation and translatability (84-98). Since the polyglot translator-editor Rónai was something of an authority figure for Lenard, and as Rónai also theorized literary translation in several essays, one might wonder how their dialog may have influenced the strategies and ideas of translation that Lénárt-Cheng and Vajdovics discern in Lenard's work.

Kerényi's possible influence on Lenard is hard to document: the authors assert that Lenard's correspondence with Kerényi is at the Deutsches Literaturarchiv Marbach (56), but its extent is unclear, and Lenard only seems to mention him in print once. Still, since Kerényi was an important presence among Lenard's Hungarian contacts, he might deserve more than passing mention. Kerényi was part of the literary and intellectual circle around the Hungarian Academy in Rome in the brief period between 1945 and 1949, when a whole generation of Hungarian scholars and artists spent shorter or longer time there. Lenard, who was hired as the Academy's physician, became acquainted with many of the visiting scholars there, including Balázs Lengyel, Ágnes Nemes Nagy, Ferenc Karinthy, Sándor Weöres, and others. As Lénárt-Cheng and Vajdovics show, this period and these friendships established Lenard's connections to Hungarian literary culture (35-36, 61-62). A decade or two older than these young writers, and an important influence on several of them, Kerényi was a charismatic academic who looked to the culture of the ancient Mediterranean for an antidote to the troubles of modernity and defined the vision of antiquity held by many mid twentieth-century classicists. His understanding of the interdependence of culture and landscape over the historical longue durée resonates with Lenard's meditations about his South-American world.

Hungary's most important twentieth-century classical scholar, Kerényi midwived a renaissance of the translation of the classics into Hungarian, helping to consolidate the classicizing literary modernism of the mid-century. Kerényi's 1935 bilingual anthology of Hungarian translations of Horace, Horatius Noster, was an important document of this trend, and Kerényi's student Gábor Devecseri - a virtuoso of metrical form and a major translator of the classics, whom the appendix to the volume identifies as another correspondent of Lenard - a key figure. Lenard's translation of Winnie-the-Pooh into classical Latin is a humanistic exercise that is part of this mid-century phenomenon. Similarly, Lenard's praise of rural recluse and the aversion to modern urban life he expressed in his last memoir, while biographically motivated, were also postures consciously modeled on Horace (69), whereas his specific pronouncements about modern life were derived from the critical discourse about modernity that flourished in the interwar years. While Mihály Babits (Lenard translated poems by Babits into German and sent his translations to the poet in the 1930s: 23, 141) must have been an important point of orientation for Lenard in all these regards, Lenard's disquisitions on the cultivation of gardens also have parallels in the writings of Béla Hamvas and László Németh, two major essayists orbiting around Kerényi in the 1930s, whether Lenard had a visceral dislike for Németh (52) or not. 
Kiséry, András. "Lénárt-Cheng, Helga, and Zsuzsa Vajdovics. 2015. Lénárd Sándor: Világok Vándora ['Alexander Lenard: Wanderer of Worlds']. Budapest: L'Harmattan. 180 pp. Illus.” Hungarian Cultural Studies. e-Journal of the American Hungarian Educators Association, Volume 10 (2017): http://ahea.pitt.edu DOI: 10.5195/ahea.2017.282

Lénárt-Cheng and Vajdovics give detailed attention to the genesis and success of Winnie ille $\mathrm{Pu}$ (1959). Once the Latin bestseller made him famous, publishers suddenly became interested in Lenard, who until then had only self-published collections of German poems and popularizing Italian medical science books to his name (including a few translations into Italian:34; his 1948 translation of Fritz Kahn's Our sex life: a guide and counsellor for everyone, which remained in print for decades afterward, does not appear in the allegedly complete bibliography of the book at hand). After a decade-long pause in which he was only writing for small émigré papers, in 1959 Lenard started working for major publishers and launched on a literary career. In addition to the books he authored in the last decade of his life, his publications include a Latin translation of Françoise Sagan's Bonjour Tristesse, as well as German translations of Antal Szerb's A királyné nyaklánca ['The Queen's Necklace'] and György G. Kardos's Avraham Bogatir hét napja (Ralph Manheim's English translation, Avraham's good week, was made from Lenard's German translation), two major twentieth-century Hungarian novels.

The translation of Szerb's book became another turning point in Lenard's life. He sent the book to Klári Szerb, Antal Szerb's widow, and thus began an excited and passionate correspondence between the two. György Spiró, who has recently written a well-researched play about the stunning Mengele-incident of Lenard's life, thinks that their correspondence is nothing short of a long-distance love affair (Gábor Miklós, "A magyar, akit Mengelének hittek" Népszabadság, May 8, 2016, http://nol.hu/kultura/a-magyar-akit-mengelenek-hittek-1614661). Lénárt-Cheng and Vajdovics are more cautious in their assessment, but they do emphasize Klári Szerb's importance for Lenard's final, most productive decade, and their use of the correspondence both shows the intensity of the relationship and indicates what a rich mine of information the letters might be. It was Klári Szerb who urged Lenard to produce a Hungarian version of his Kuh auf dem Bast, and even more importantly, to write his last book, Egy nap a láthatatlan házban (43, 62-64). An exploration of the exchanges between Lenard and Szerb around this work might also supplement its brief discussion by Lénárt-Cheng and Vajdovics, whose focus is on the complications of "autobiography" as a genre (76-83) and who also draw on it throughout the book for the biographical information it conveys. One might also note that Egy nap is an erudite and anecdotal personal essay, and wonder whether the digressive style of this last book might not itself be due to Lenard's encounter with Antal Szerb, first through the translation of his novel, and then through Klári Szerb, who provided Lenard with a steady stream of books, including an edition of Antal Szerb's essays.

Although Lenard's most likely bestseller now seems to be his Római történetek ['Stories of Rome'], his other writings, including his essays about languages, the cultural history of cuisine, and about other topics, are likely to enjoy continuing interest. His books have been discussed as examples of life-writing, of self-translation, and of exilic writing, but the formalist analyses offered by the authors of this volume, and the biographical and philological research of Péter Siklós (whose work seems inadequately acknowledged in the footnotes to the first chapter) leave plenty of room for intellectual-historical and literary-historical questions, as well as for further attention to the substance of Lenard's essayistic prose. In writing about migration, language, nature, and society, he displayed a sensibility that is ecological and global, and he might now be more valued as an interlocutor than he was by his own contemporaries. 
Kiséry, András. "Lénárt-Cheng, Helga, and Zsuzsa Vajdovics. 2015. Lénárd Sándor: Világok Vándora ['Alexander Lenard: Wanderer of Worlds']. Budapest: L'Harmattan. 180 pp. Illus." Hungarian Cultural Studies. e-Journal of the American Hungarian Educators Association, Volume 10 (2017): http://ahea.pitt.edu DOI: 10.5195/ahea.2017.282

The book would have benefited from further revision and editorial attention. This is nowhere more in evidence than in the bibliography, which should be a major help for readers and future researchers, but which I found very hard to use. While readers may disagree whether the authors' thematic-generic approach is entirely successful, an index would definitely have made it easier to locate references to individual events, people, and works in this wide-ranging study. A better apparatus would also have further helped the authors achieve their goal: to encourage further research into Lenard's fascinating life and work. 